\title{
What are Teacher's Needs Concerning Augmented Reality Digital Authoring Tools?
}

\author{
Manoela M. O. da Silva ${ }^{1}$, Veronica Teichrieb ${ }^{1}$, Patricia Smith Cavalcante ${ }^{2}$ \\ ${ }^{1}$ Voxar Labs - Centro de Informática - Universidade Federal de Pernambuco (UFPE) \\ Recife - PE - Brazil \\ ${ }^{2}$ Edumatec - Centro de Educação - Universidade Federal de Pernambuco (UFPE) \\ Recife - PE - Brazil \\ \{mmos,vt\}@cin.ufpe.br, patricia3smithegmail.com.br
}

\begin{abstract}
This Ph.D. research aims to investigate authoring tools for augmented reality (AR) applications devoted to education. We investigate teacher's ways of work, how they prepare their lessons and select materials to be used as well as how current technology has been used in their practice. Based on the results, we will propose an authoring tool that would make sense to teacher's needs and abilities and would be coherent with the constraints they might face.
\end{abstract}

Resumo. Esta pesquisa de doutorado visa investigar ferramentas de autoria para aplicações de realidade aumentada (RA) na educação. Investigamos as formas de trabalho do professor, como preparam suas aulas e selecionam os materiais a serem utilizados e como a tecnologia atual tem sido usada em sua prática. Com base nos resultados, iremos propor uma ferramenta de autoria que faça sentido para as necessidades e habilidades do professor e seja coerente com as restrições que eles possam enfrentar.

\section{Problem Statement}

AR consists of adding virtual elements to a real scene coherently so that ideally users cannot differentiate them from the real scene [Azuma 1997]. Unlike other computer interfaces that draw users away from the real world and onto the screen, AR enhance the real world experience. AR educational experiences are different due to numerous reasons, including: (a) support of seamless interaction between real and virtual environments, (b) use of a tangible interface metaphor for object manipulation, and (c) ability to transition smoothly between reality and virtuality [Billinghurst and Duenser 2012]. However, for these tools to be widespread in this field it is important to have suitable authoring tools as time and technical expertise are two of the reasons that hinder the far-reaching use of authoring tools [Roberto et al. 2016]. Thus, we observe the need to work on AR authoring tools for education. We believe that simpler and easier to use authoring tools would enable much more AR exploration in the classrooms.

\section{Objectives}

Our research question is what are the specific needs for AR authoring tools aimed at education? The main objective is to investigate teacher's use of technology, particularly, AR to identify their needs for authoring. Our research hypotheses is that from the identification of teacher's AR authoring needs, we can expand AR pedagogic possibilities. This research has been developed for 41 months. It will last until February, 2020. 
VIII Congresso Brasileiro de Informática na Educação (CBIE 2019)

Anais dos Workshops do VIII Congresso Brasileiro de Informática na Educação (WCBIE 2019)

\section{Related Works}

Coexistence of virtual and real information allowed by AR enables learners to visualize complex spatial relationships and abstract concepts [Radu and Schneider 2019]. Other AR capabilities that can be explored in education are its ability to improve how users receive and follow instructions, and its capacity to transform the way users interact with and control products [Microsoft 2015]. Works investigating and evaluating AR in education has been increasing [da Silva et al. 2019]. AR has been correlated to a positive impact on students' motivation [Radu 2014] and cognitive performance [Theodorou et al. 2018]. Despite these learning opportunities, AR applications are still not widely used in education. Many factors can influence teachers' technology adoption, such as their own technology skills and educational beliefs. Social learning and support in workplace environments, the tools available as well as the possibility of customization of educational experiences also play a role in teachers' adoption of technology [Vermette et al. 2019].

Authoring tools can be categorized in two broad categories: AR authoring for programmers and for non-programmers [Roberto et al. 2016]. The former requires programming knowledge from the user and usually refers to code libraries (e.g: ARToolkit). The latter refers to tools, in which abstraction is added and low level programming ability is removed or hidden. The non-programmer, or content design tools, are content-driven and usually include graphical user interfaces for building applications without writing any lines of code. For this work, the latter category will be explored. Many content-design tools have been developed although few of them are aiming to the field of education. [Barone Rodrigues et al. 2015] carried out a systematic review about AR authoring tools for education and found out only four studies regarding that matter. These works lacked the possibility of reuse of the material created by the users.

[Locatis and Al-Nuaim 1999] highlight the importance of analyzing the authoring tools and the context in which they will be used. They stress the importance of evaluating these aspects in relation to technology and product life cycles along with business and marketing strategies contributing to a technology success. Other works have investigated this issue [Vert and Andone 2017], however, they usually base their decisions only on scientific literature. Thus, our main difference is that we investigate AR authoring tools for education using a design-based approach.

\section{Methodology}

This research uses the design-based approach whose ultimate goal is to build a stronger connection between educational research and real-world problems [Amiel and Reeves 2008]. Design-based research (DBR) calls for iterative cycles of study that lead to a better understanding of the process of intervention (process-oriented). It has five characteristics: interventionist, iterative, process-oriented, utility oriented and theory oriented. This choice is based on the nature of the problem we tackle in this research. As pointed out by [Amiel and Reeves 2008], "integrating technologies into the classroom leads to substantial changes in social organization, student-teacher relationships, and a myriad of other factors that cannot be investigated successfully by predictive research."

The first stage of a DBR consists in an "analysis of practical problems by researchers and practitioners in collaboration". This first step involved the application of semi-structured interviews with 7 teachers and 2 coordinators who used AR to investigate 
teacher's ways of work, how they prepare their lessons and select materials to be used as well as how AR technology has been used in their practice [Silva et al. 2018]. The data was analyzed following the phases of thematic analysis [Braun and Clarke 2006]. The unit of analysis was all teachers' responses considered together. We also conducted an online structured survey with 106 teachers to gather information about the current maturity level of AR adoption in schools, and the constraints blocking AR to be used in the classrooms [Silva et al. 2019]. These questions were based on the Future Classroom maturity model [Future Lab 2014]. The data collected helped the researcher to create personas of the teachers and storyboards that represent teacher's AR use and creation creation process [Martin et al. 2012]. For this stage, we aimed to recruit participants that represented a broadcross-section across teaching levels and subjects.

After, ideation sessions were conducted with teachers, developers and designers to understand what teachers would like to do with AR and how they could customize AR content for learning purposes. For this stage, we focused on foreign language teaching to teenage students in Brazil and in the US. Our main goal was to extract requirements needed for an AR authoring tool. These sessions were inspired in the sprint method practices [Knapp et al. 2017], which focuses on prototyping and testing ideas with customers in an agile format. Their output were the map of the problems faced by the teachers, sketches of possible solutions and a detailed storyboard of the solution proposed.

The next step in DBR is described as "Iterative cycles of testing and refinement of solutions in practice". In this ongoing process, we are finishing a prototype to validate with teachers. The first cycle will involve a low fidelity prototype, which will be iterated based on the feedback received. These cycles are intended to be conducted until a particular version of the prototype presents desired results, which means that it will meet teachers' needs. At least two cycles of user tests will be conducted in this research.

The last cycle in DBR is a "reflection to produce "design principles" and enhance solution implementation". This means that the data gathered will be reflected upon to generate guidelines for the development of an AR authoring tool aimed at education.

\section{Results and Final Considerations}

The interviews and the survey have indicated that although teachers seem interested in learning about AR, its use has not reached higher levels of maturity in schools yet. Different aspects were found to contribute to this, such as lack of infrastructure, authoring tools and time. Teachers also need more guidance and support to better connect AR use with their pedagogic goals. These results suggest that teachers believe that more authoring tools could enable much more exploration in the classrooms. As regards the existing content creation tools, data have shown that the teachers who created AR content usually have issues regarding user-friendliness.

Our research has evidenced some aspects that are important to be considered in AR authoring tools development, namely: (a) user-friendliness; (b) offline version; (c) mobile version; (d) personalization ; (e) assessment flexibility; (f) collaboration between users; (g) collaborative authorship; (h) sharing AR experiences; (i) content curation; (j) statistics; (k) complex controls; and (l) location based-content. Other aspects might also need consideration, such as support to teachers and the cost of the tools.

Based on our results, we chose a challenge to focus on during the ideation ses- 
VIII Congresso Brasileiro de Informática na Educação (CBIE 2019)

Anais dos Workshops do VIII Congresso Brasileiro de Informática na Educação (WCBIE 2019)

sions: "How might we design a learning sequence using AR to help students understand ELA $^{1}$ concepts in small groups?" We raised different problems teachers face regarding the proposed challenge. These problems were correlated with AR's potential. The problems chosen to be tackled are: student dependency of the teacher and students lack of understanding the topic. Technology restrictions were also shared with participants. We chose to use Microsoft Hololens [Microsoft 2019] due to its flexibility. Teachers were prompted to think about what they would like to use AR for.

We aim to propose an AR application to be the base for the authoring tool. The storyboard of a solution named Virtual Playground was developed. It intends to help students learn language through storytelling. A prototype of this tool is currently being developed. Many characteristics found in our research are being incorporated into the prototype. For instance, it will allow collaboration between students to produce content. Also, both teachers and students will be able to provide input in the creation process. it will also enable users to create and share the content intuitively. The interface of the prototype is being created using Figma ${ }^{2}$, while the prototype of the tool is being developed using Vuforia ${ }^{3}$ and Unity ${ }^{4}$. Thus, an AR authoring tool will be proposed to create content for this application considering the data collected in this research. This prototype will be validated with teachers to understand what kinds of lessons they can create using AR.

As limitations, teachers who used AR can be considered pioneers and may not represent the whole population. Also, we understand that solving the problems discussed in this work might not directly cause teachers to use AR in more advanced levels. Behavioral elements and circumstances at workplace also play a role in teachers adoption of new technology and its effective use. These aspects are not in direct control of developers.

\section{Acknowledgements}

Authors would like to thank the participants and Fundação de Amparo a Ciência e Tecnologia de Pernambuco (FACEPE) (processes IBPG-0605-1.03/15) for their funding.

\section{References}

Amiel, T. and Reeves, T. C. (2008). Design-based research and educational technology: Rethinking technology and the research agenda. Educational Technology \& Society, 11(4):29-40.

Azuma, R. T. (1997). A survey of augmented reality. Presence: Teleoper. Virtual Environ., 6(4):355-385.

Barone Rodrigues, A., Dias, D. R., Martins, V., and Guimaraes, M. (2015). Augmented reality authoring tools for education: systematic review.

Billinghurst, M. and Duenser, A. (2012). Augmented reality in the classroom. Computer, 45(7):56-63.

Braun, V. and Clarke, V. (2006). Using thematic analysis in psychology. Qualitative Research in Psychology, 3(2):77-101.

\footnotetext{
${ }^{1}$ English, Language and Arts.

${ }^{2}$ https://www.figma.com/

${ }^{3}$ https://developer.vuforia.com/

${ }^{4}$ https://unity.com
} 
VIII Congresso Brasileiro de Informática na Educação (CBIE 2019)

Anais dos Workshops do VIII Congresso Brasileiro de Informática na Educação (WCBIE 2019)

da Silva, M. M. O., Teixeira, J. M. X. N., Cavalcante, P. S., and Teichrieb, V. (2019). Perspectives on how to evaluate augmented reality technology tools for education: a systematic review. JBCS, 25(1):3.

Future Lab (2014). Future Classroom Maturity Model reference guide. https : / / bit . 1 y / 2xQ8YHq. Accessed: May 8th, 2019.

Knapp, J., Zeratsky, J., and Kowitz, B. (2017). Sprint: O método usado no Google para testar e aplicar novas ideias em apenas cinco dias. Intrínseca.

Locatis, C. and Al-Nuaim, H. (1999). Interactive technology and authoring tools: A historical review and analysis. Educational Technology Research and Development, 47(3):63-75.

Martin, B., Hanington, B., and Hanington, B. (2012). Universal Methods of Design: 100 Ways to Research Complex Problems, Develop Innovative Ideas, and Design Effective Solutions. Rockport Publishers.

Microsoft (2015). Microsoft HoloLens: Partner Spotlight with Case Western Reserve University. https: / / bit. Iy/1 furHgQ. Accessed: 2019-05-07.

Microsoft (2019). Microsoft Hololens 2. https : / / www . microsoft . com/en-us / hololens. Accessed: June 3rd, 2019.

Radu, I. (2014). Augmented reality in education: a meta-review and cross-media analysis. Personal and Ubiquitous Computing, 18(6):1533-1543.

Radu, I. and Schneider, B. (2019). What can we learn from augmented reality (ar)? In Proceedings of the 2019 CHI Conference on Human Factors in Computing Systems, CHI '19, pages 544:1-544:12, New York, NY, USA. ACM.

Roberto, R. A., Lima, J. P., Mota, R. C., and Teichrieb, V. (2016). Authoring tools for augmented reality: An analysis and classification of content design tools. Design, User Experience, and Usability at HCII, pages 237-248.

Silva, M., Roberto, R., Radu, I., Cavalcante, P., and Teichrieb, V. (2019). Why don't we see more of augmented reality in schools? Proceedings of IEEE ISMAR 2019, Poster accepted for publication.

Silva, M. M. O. d., Radu, I., Schneider, B., Cavalcante, P. S., and Teichrieb, V. (2018). An investigation on how teachers are using augmented reality in their lessons. In Anais do XXIX SBIE. Sociedade Brasileira de Computação.

Theodorou, P., Kydonakis, P., Botzori, M., and Skanavis, C. (2018). Augmented reality proves to be a breakthrough in environmental education. Protection and Restoration of the Environment.

Vermette, L., McGrenere, J., Birge, C., Kelly, A., and Chilana, P. K. (2019). Freedom to personalize my digital classroom: Understanding teachers' practices and motivations. In Proceedings of the 2019 CHI, CHI '19, pages 318:1-318:14, New York, NY, USA. ACM.

Vert, S. and Andone, D. (2017). Zero-programming augmented reality authoring tools for educators: Status and recommendations. In 2017 IEEE 17th ICALT, pages 496-498. 